\title{
From eye rolls to punches: experiences of harm from others' drinking among risky- drinking adolescents across Australia
}

\section{Tina Lamª,b, Anne-Marie Lasletta,c, Rowan P Ogeil b,d,e, Dan I Lubman ${ }^{\mathrm{b}, \mathrm{d}, \mathrm{e}}$, Wenbin Lianga, Tanya N Chikritzhsa ${ }^{a}$, William T Gilmore ${ }^{a}$, Simon R Lentona, Jane Fischer ${ }^{f}$, Alexandra Aiken', Richard P Mattick' ${ }^{\text {, Lucinda A Burns }}{ }^{9}$, Richard Midfordh,i and Steve J Allsopa}

\footnotetext{
a National Drug Research Institute, Faculty of Health Sciences, Curtin University, Perth, WA, Australia

b Monash Addiction Research Centre, Monash University, Melbourne, VIC, Australia

c Centre for Alcohol Policy Research, La Trobe University, Melbourne, VIC, Australia

d Turning Point, Eastern Health, Melbourne, VIC, Australia

e Eastern Health Clinical School, Monash University, Melbourne, VIC, Australia

${ }^{\dagger}$ National Centre for Education and Training on Addiction, Flinders University, Adelaide, SA, Australia

g National Drug and Alcohol Research Centre, UNSW Sydney, Australia

h Charles Darwin University, Darwin, NT, Australia

Menzies School of Health Research, Darwin, NT, Australia

j Corresponding author: tina.lam@monash.edu
}

\section{Article history}

Publication date: December 2019

Citation: Lam T, Laslett AM, Ogeil RP, Lubman DI, Liang W, Chikritzhs TN, Gilmore WT, Lenton SR, Fischer J, Aiken A, Mattick RP, Burns LA, Midford R, Allsop SJ. From eye rolls to punches: experiences of harm from others' drinking among risky-drinking adolescents across Australia. Public Health Res Pract. 2019;29(4):e2941927.

https://doi.org/10.17061/phrp2941927

\section{Key points}

- Young people and risky drinkers are susceptible to experiencing alcohol's harms to others (AHTO)

- Women report more fear and harassment-based AHTO than men, while males report more aggressive AHTO

- Teenagers of a legal alcohol-purchase age experience more AHTO such as harassment in public settings and unwanted sexual attention

- Adverse effects such as verbal or physical abuse are more commonly perpetrated by individuals known to victims, while fear-based harms are more commonly attributed to strangers

\section{Abstract}

Objectives: Exploration of experience of harms due to another person's drinking within a demographic particularly vulnerable to these consequences.

Importance of study: Largest sampling of young Australian risky drinkers, who are underrepresented in general population surveys. The range of harms due to others' drinking reported here is more comprehensive than documented elsewhere.

Study type: Cross-sectional self-report survey.

Methods: Participants were 14-19 years old and screened as being within the riskiest-drinking $25 \%$ for their age cohort. The convenience sample of 3465 was recruited primarily by social media advertising. Face-to-face interviews were conducted in all eight Australian capital cities ( $n=596)$, supplemented by online surveys $(n=2869)$. Past 12-month experience of 13 harms due to others' drinking was assessed by age, gender and perpetrator.

Results: Females were more likely to experience seven harms, mainly characterised by fear and harassment, including being harassed or bothered at a party or some other private setting ( $41 \%$ vs $34 \%$ of males, $p<0.001$ ), being given unwanted sexual attention $(71 \%$ vs $47 \%, p<0.001)$ and being put in fear $(33 \%$ vs $20 \%, p<0.001)$. Males were more likely 
to experience three harms, characterised by aggression: being yelled at, criticised or verbally abused (38\% vs 33\% of females, $p=0.002$ ), being pushed or shoved (42\% vs 28\%, $p<0.001$ ) and being physically hurt ( $17 \%$ vs $11 \%, p<0.001)$. Teenagers of a legal alcoholpurchase age were more likely to experience harassment in public settings (49\% vs 32-34\%, $p<0.001$ ) and unwanted sexual attention (66\% vs $51-59 \%, p<0.001)$ compared with younger teenagers. Seven of the harms studied were more likely $(p<0.01)$ to be perpetrated by people the respondents knew, and five (those associated with fear and aggression) were more likely to be perpetrated by strangers.

Conclusion: Young people who are risky drinkers commonly experience multiple harms from others' drinking. Many of these alcohol harms to others are reported here for the first time, as previous studies of adolescent drinking have focused almost exclusively on the harms young people have experienced from their own drinking. This refocusing on the harms caused by the drinking of others may prompt greater community concern and concomitant calls for better alcohol regulation.

\section{Introduction}

Traditionally, research on alcohol has focused on its harmful effects on drinkers themselves. However, increasingly, researchers and policy makers are considering alcohol's harms to others (AHTO), or its second-hand effects. Annually, an estimated 162400 Australians aged 18 years and older experience physical assault from individuals they believed were under the influence of alcohol ${ }^{1}$, and $40 \%$ of deaths due to interpersonal violence are associated with another person's drinking. ${ }^{2}$ In addition to incidents requiring emergency responses, AHTO also includes work absenteeism/presenteeism and vandalism. ${ }^{3}$

Being younger and being a riskier drinker are two risk factors for experiencing AHTO, meaning 'social victims of drinkers' are demographically similar to 'problem drinkers'; and that alcohol likely has both a criminogenic and a victimogenic influence (i.e. it contributes to both perpetration and victimisation). ${ }^{4}$

Riskier drinkers report experiencing higher rates of AHTO. While $19 \%$ of the Australian general population reported verbal abuse by a drinker in the past 12 months, $29 \%$ of those considered 'risky drinkers' reported this behaviour. ${ }^{5}$ However, the experience of AHTO is not always related to personal alcohol use, and the majority of abstainers were still likely to experience at least one kind of AHTO in the previous 12 months. ${ }^{6}$ One-fifth of Canadian undergraduate abstainers reported having been insulted or humiliated by a drinker ${ }^{7}$, and Australian undergraduates' reports of sexual assault by a drinker were not associated with the frequency of the victim's risky drinking. ${ }^{8}$
Being younger is associated with a greater likelihood of victimisation. Australians aged 18-29 years are almost three times as likely as older adults to report an alcoholrelated harm such as verbal or physical abuse. ${ }^{9}$ The most common AHTO experienced by 4000 Australian undergraduates aged 17-19 years were having to 'babysit' another student (32\%), having their studying or sleep interrupted (22\%), and having a serious argument or quarrel (14\%). ${ }^{8}$ After controlling for their own drinking patterns, students' experiences of AHTO are predictive of broader negative outcomes such as depression ${ }^{10}$ and impaired school performance. ${ }^{7}$ Among the 1300 youths aged 14-19 years surveyed in the 2016 National Drug Strategy Household Survey (of which 600 drank alcohol in the past 12 months), 14\% reported verbal abuse, $5 \%$ reported physical abuse and $12 \%$ were put in fear by a drinker in the past 12 months. ${ }^{5}$ Gender, Caucasian ethnicity, urbanicity, living away from parents, personality type and attending a college with riskier-drinking students are also risk factors for students' AHTO experience. .,11,12 $^{2}$ Young women are more likely than young men to experience unwanted sexual advances and having to take care of someone who has had too much to drink $^{8}$, and young men are more likely to be pushed, hit or assaulted. ${ }^{11}$

Data for this study are drawn from the Young Australians Alcohol Reporting System (YAARS). YAARS targets young risky drinkers who are underrepresented in national surveys but particularly vulnerable to alcoholrelated harm. ${ }^{13-17}$ To our knowledge, YAARS is the largest national youth dataset that describes AHTO. This study sought to provide insight into young risky drinkers' experience of 13 AHTO that have not been assessed elsewhere, and how these harms varied by participant gender, age and whether or not they knew the perpetrator. 


\section{Methods}

\section{Participants}

We developed selection criteria using relevant data sources $^{18-20}$ to identify the consumption patterns of the riskiest-drinking quartile of each age and gender cohort. One Australian standard drink (SD) is equivalent to $10 \mathrm{~g}$ of alcohol. The 14-15-year-olds were consuming $\geq 1 \mathrm{SD}$ in a single sitting at least once a month; 16-17-yearolds had $\geq 5$ SD per occasion at least twice per month; 18-19-year-old females had $\geq 7$ SD per sitting at least twice per month; and 18-19-year-old males were drinking $\geq 9$ SD per occasion at least twice per month.

A convenience sample was recruited through agetargeted social media (Facebook and Instagram) advertisements, referrals by peers and poster advertisements at educational facilities and youth services. ${ }^{21}$

\section{Procedure}

Data were collected between October-November 2016 and mid-January-March 2017. Two survey modalities were used: face-to-face interview $(n=596)$ and a shorterduration self-administered online survey $(n=2869)$. The 45-minute interviews were confidential and conducted in locations such as public cafes in all eight Australian capital cities. Interview participants were reimbursed \$AUD40 for their time and transport. The 20-minute online survey, which included a prize draw, allowed for a lower-cost inclusion of a broader sample (e.g. regional participants). Findings were broadly consistent across both modalities and detailed descriptions of the procedure are available elsewhere. ${ }^{21}$ Participants provided informed consent and all participating sites had institutional ethics approval: Curtin University (HR 52/2014), UNSW Sydney (HR 52/2014), Monash University (1032), University of Tasmania (H16018), Flinders University (OH-00111), ACT Health Research Records and Governance Office (ETH.9.16.185), Charles Darwin University (H16094) and University of Queensland (2016001535).

\section{Measures}

Respondents were asked: "In the past 12 months has someone who has been drinking ..." perpetrated any of the 13 harms of interest. Items relevant to young people were selected from an international AHTO study that one of the co-authors codeveloped (psychometric data unavailable). ${ }^{22,23}$ The four dummy-coded response options for experience of the harms were: a) yes - by someone I know; b) yes - by a stranger; c) no; and d) unsure.
For ease of analysis by age and gender, the first two categories were collapsed into 'yes', and the latter two combined into 'no or unsure'.

\section{Data analysis}

Z-tests were used to compare whether experience of the 13 AHTO varied by gender (male vs female), age (14-15, 16-17 and 18-19) and perpetrator of the AHTO (known vs unknown).

Respondents who identified as transgender $(n=16)$, or who preferred not to state their gender $(n=22)$, were excluded from the gender analysis due to small group size, but were included elsewhere.

All analyses were computed with SPSS Statistics for Windows (Armonk, NY: IBM Corp; version 24.0).

\section{Results}

\section{Participants}

Most of the convenience sample were recruited through age-targeted social media advertisements (70\% Facebook, 17\% Instagram), 14\% were referred through a friend, $2 \%$ saw a poster at their educational facility and $1 \%$ were recruited through a youth service $(N=2818)^{21}$. Not all participants responded to all items, so the $N=2869$ sample size reflects the sample size for the item reported on. The demographics of participants are detailed in Table 1.

Across age and gender groupings, $75 \%$ of the total sample $(N=3465)$ were consuming $\geq 9$ SD in a single session at least monthly. Monthly drinking in private locations (e.g. homes) appeared similar across age groups (88\% in 14-17-year-olds, 94\% in 18-19-yearolds, $N=2826)$, whereas visits to licensed venues were more common among 18-19-year-olds (86\%), who can legally purchase alcohol, compared to 14-17-year-olds $(13 \%, N=2830)$. 
Table 1. Participant demographics

\begin{tabular}{|c|c|c|c|}
\hline Characteristic & Category & $n$ & $\%$ \\
\hline \multirow[t]{5}{*}{ Gender } & Male & 1472 & 42.5 \\
\hline & Female & 1948 & 56.2 \\
\hline & Transgender & 19 & 0.5 \\
\hline & $\begin{array}{l}\text { I do not identify as any } \\
\text { of the above/prefer not } \\
\text { to say }\end{array}$ & 26 & 0.8 \\
\hline & Total & 3465 & \\
\hline \multirow[t]{4}{*}{ Age (years) } & $14-15$ & 568 & 16.4 \\
\hline & $16-17$ & 1442 & 41.6 \\
\hline & $18-19$ & 1455 & 42.0 \\
\hline & Total & 3465 & \\
\hline \multirow[t]{8}{*}{ Occupation } & School student & 1791 & 52.8 \\
\hline & University student & 990 & 29.2 \\
\hline & Technical college student & 156 & 4.6 \\
\hline & Employed full time & 132 & 3.9 \\
\hline & Trade apprentice & 82 & 2.4 \\
\hline & Unemployed & 215 & 6.3 \\
\hline & Other & 29 & 0.9 \\
\hline & Total $^{\mathrm{a}}$ & 3395 & \\
\hline \multirow{4}{*}{$\begin{array}{l}\text { Place of birth/ } \\
\text { parents place } \\
\text { of birth }^{b}\end{array}$} & $\begin{array}{l}\text { Participant was born } \\
\text { overseas }\end{array}$ & 317 & 9.3 \\
\hline & $\begin{array}{l}\text { At least one parent born } \\
\text { overseas }\end{array}$ & 1291 & 38.1 \\
\hline & $\begin{array}{l}\text { Participant and parents } \\
\text { all born in Australia }\end{array}$ & 2025 & 59.7 \\
\hline & Total $^{\mathrm{a}}$ & 3392 & \\
\hline \multirow{3}{*}{$\begin{array}{l}\text { Languages } \\
\text { spoken at } \\
\text { home }\end{array}$} & English only & 2833 & 88.9 \\
\hline & $\begin{array}{l}\text { English and another } \\
\text { language(s) }\end{array}$ & 354 & 11.1 \\
\hline & Total $^{\mathrm{a}}$ & 3187 & \\
\hline
\end{tabular}

a Total $=$ valid sample size for each item (not all participants responded to every item)

b Participants could select both the option of "participant was born overseas" and "at least one parent born overseas" so percentages do not sum to $100 \%$.

\section{AHTO by gender}

Almost all of those surveyed (94\%) experienced a harm due to someone else's drinking in the past 12 months (Table 2). On average, participants reported five AHTO. The most commonly reported AHTO were having a party or social gathering ruined (65\%), receiving unwanted sexual attention $(61 \%)$, social aggression $(51 \%)$, having their clothing or other belongings ruined (47\%), and public harassment (40\%).

There were significant gender differences in 10 of the 13 AHTO, with females more likely than males to have experienced at least one AHTO in the past 12 months.

AHTO by age

Older respondents were more likely to have experienced seven of the 13 AHTO, with the exception being that a greater proportion of 14-15-year-olds reported being put in fear by a drinker compared with 16-17-year-olds (Table 3).

\section{AHTO by perpetrator}

In 12 of the 13 AHTO, there was a significant difference in the proportion of known vs unknown perpetrators reported (Table 4). Similar proportions reported unwanted sexual attention from known individuals and strangers, and a small proportion (about 10\%) reported perpetrators were both known and unknown. 
Table 2. Harms experienced due to others' drinking in the past 12 months, all participants and by gender

\begin{tabular}{|c|c|c|c|c|c|c|c|c|c|}
\hline \multirow[b]{2}{*}{ Harms experienced ${ }^{a}$} & \multicolumn{2}{|c|}{ All participants } & \multicolumn{2}{|c|}{ Male } & \multicolumn{2}{|c|}{ Female } & \multicolumn{3}{|c|}{$\begin{array}{l}\text { Two proportion Z-test for } \\
\text { differences by gender }\end{array}$} \\
\hline & $\%$ & $N$ & $\%$ & $N$ & $\%$ & $N$ & Z & $p$ & $\begin{array}{l}\text { More } \\
\text { likely }^{b}\end{array}$ \\
\hline Ruined a party or social gathering & 65.1 & 2873 & 63.0 & 1178 & 66.7 & 1657 & 2.07 & 0.038 & Female \\
\hline $\begin{array}{l}\text { Ruined your clothes or other } \\
\text { belongings }\end{array}$ & 47.3 & 2866 & 48.8 & 1169 & 46.5 & 1659 & 1.20 & 0.231 & - \\
\hline $\begin{array}{l}\text { Given you unwanted sexual } \\
\text { attention }\end{array}$ & 61.0 & 2860 & 47.0 & 1169 & 70.8 & 1654 & 12.78 & $<0.001$ & Female \\
\hline $\begin{array}{l}\text { Done something socially } \\
\text { aggressive }^{c}\end{array}$ & 50.7 & 2863 & 50.6 & 1170 & 51.1 & 1655 & 0.24 & 0.810 & - \\
\hline $\begin{array}{l}\text { Made you afraid when you } \\
\text { encountered them on the street }\end{array}$ & 38.6 & 2860 & 30.0 & 1169 & 44.3 & 1653 & 7.67 & $<0.001$ & Female \\
\hline $\begin{array}{l}\text { Harassed or bothered you at } \\
\text { a party or some other private } \\
\text { setting }\end{array}$ & 38.0 & 2858 & 33.8 & 1166 & 40.8 & 1654 & 3.78 & $<0.001$ & Female \\
\hline $\begin{array}{l}\text { Harassed or bothered you on the } \\
\text { street or in a public place }\end{array}$ & 39.9 & 2853 & 35.9 & 1166 & 42.5 & 1650 & 3.50 & $<0.001$ & Female \\
\hline $\begin{array}{l}\text { Left you alone in an unsafe } \\
\text { situation }\end{array}$ & 24.8 & 2860 & 15.1 & 1169 & 31.5 & 1654 & 9.92 & $<0.001$ & Female \\
\hline $\begin{array}{l}\text { Yelled at, criticised or verbally } \\
\text { abused you }\end{array}$ & 35.3 & 2848 & 38.4 & 1161 & 32.7 & 1649 & 3.13 & 0.002 & Male \\
\hline Pushed or shoved you & 34.1 & 2858 & 42.4 & 1170 & 28.0 & 1650 & 7.95 & $<0.001$ & Male \\
\hline Physically hurt you & 14.0 & 2857 & 17.4 & 1166 & 11.3 & 1653 & 4.62 & $<0.001$ & Male \\
\hline Put you in fear & 27.9 & 2847 & 20.4 & 1162 & 32.8 & 1647 & 7.23 & $<0.001$ & Female \\
\hline $\begin{array}{l}\text { Engaged in serious violence that } \\
\text { you witnessed }\end{array}$ & 34.2 & 2849 & 35.2 & 1162 & 33.6 & 1650 & 0.89 & 0.372 & - \\
\hline $\begin{array}{l}\text { At least one of the } 13 \text { AHTO } \\
\text { experienced in past } 12 \text { months }\end{array}$ & 93.6 & 2882 & 91.9 & 1180 & 94.7 & 1664 & 2.96 & 0.003 & Female \\
\hline
\end{tabular}

$N=$ sample size for each item

a Respondents were asked: "In the past 12 months, has someone who has been drinking ..."

b Listed gender reported a significantly $(p<0.05)$ higher proportion of experience

c Abbreviation of the phrase used in the survey: "Turned their back on you, rolled their eyes at you, gave dirty looks, ignoring you [sic] or did something else to you that was socially aggressive and designed to hurt you."

Note: Not all participants responded to all items. 
Table 3. Harms experienced due to others' drinking in the past 12 months, by age

\begin{tabular}{|c|c|c|c|c|c|c|c|c|c|c|c|c|c|}
\hline \multirow[b]{3}{*}{ Harms experienced ${ }^{a}$} & \multicolumn{6}{|c|}{ Descriptives } & \multicolumn{7}{|c|}{ Two proportion Z-test for differences by age } \\
\hline & \multicolumn{2}{|c|}{$14-15$ years } & \multicolumn{2}{|c|}{$16-17$ years } & \multicolumn{2}{|c|}{$18-19$ years } & \multicolumn{2}{|c|}{$\begin{array}{l}14-15 \text { vs } \\
16-17 \text { years }\end{array}$} & \multicolumn{2}{|c|}{$\begin{array}{c}16-17 \text { vs } \\
18-19 \text { years }\end{array}$} & \multicolumn{2}{|c|}{$\begin{array}{l}14-15 \text { vs } \\
18-19 \text { years }\end{array}$} & \multirow[t]{2}{*}{$\begin{array}{l}\text { More } \\
\text { likely }\end{array}$} \\
\hline & $\%$ & $N$ & $\%$ & $N$ & $\%$ & $N$ & Z & $p$ & Z & $p$ & Z & $p$ & \\
\hline Ruined a party or social gathering & 62.9 & 437 & 66.8 & 1208 & 64.2 & 1228 & 1.46 & 0.143 & 1.37 & 0.171 & 0.46 & 0.643 & - \\
\hline $\begin{array}{l}\text { Ruined your clothes or other } \\
\text { belongings }\end{array}$ & 40.0 & 437 & 47.5 & 1202 & 49.6 & 1227 & 2.68 & 0.007 & 1.05 & 0.294 & 3.45 & 0.001 & Older \\
\hline Given you unwanted sexual attention & 51.0 & 435 & 59.1 & 1199 & 66.4 & 1226 & 2.92 & 0.003 & 3.70 & $<0.001$ & 5.68 & $<0.001$ & Older \\
\hline Done something socially aggressive ${ }^{c}$ & 46.5 & 434 & 49.0 & 1203 & 53.8 & 1226 & 0.89 & 0.372 & 2.32 & 0.020 & 2.58 & 0.010 & Older \\
\hline $\begin{array}{l}\text { Made you afraid when you } \\
\text { encountered them on the street }\end{array}$ & 38.9 & 437 & 35.3 & 1198 & 41.7 & 1225 & 1.34 & 0.181 & 3.24 & 0.001 & 1.03 & 0.305 & Older \\
\hline $\begin{array}{l}\text { Harassed or bothered you at a party } \\
\text { or some other private setting }\end{array}$ & 36.0 & 436 & 35.5 & 1198 & 41.1 & 1224 & 0.20 & 0.842 & 2.84 & 0.004 & 1.86 & 0.062 & Older \\
\hline $\begin{array}{l}\text { Harassed or bothered you on the } \\
\text { street or in a public place }\end{array}$ & 32.3 & 436 & 33.6 & 1195 & 48.6 & 1222 & 0.49 & 0.622 & 7.48 & $<0.001$ & 5.87 & $<0.001$ & Older \\
\hline Left you alone in an unsafe situation & 25.7 & 436 & 23.5 & 1197 & 25.8 & 1227 & 0.93 & 0.355 & 1.30 & 0.193 & 0.03 & 0.978 & - \\
\hline $\begin{array}{l}\text { Yelled at, criticised or verbally } \\
\text { abused you }\end{array}$ & 35.9 & 434 & 33.1 & 1193 & 37.3 & 1221 & 1.07 & 0.285 & 2.14 & 0.033 & 0.49 & 0.625 & - \\
\hline Pushed or shoved you & 34.1 & 437 & 31.3 & 1196 & 36.8 & 1225 & 1.08 & 0.279 & 2.88 & 0.004 & 1.02 & 0.309 & Older \\
\hline Physically hurt you & 16.1 & 435 & 14.0 & 1197 & 13.1 & 1225 & 1.04 & 0.298 & 0.64 & 0.522 & 1.53 & 0.127 & - \\
\hline Put you in fear & 32.1 & 433 & 26.1 & 1197 & 28.1 & 1217 & 2.37 & 0.018 & 1.08 & 0.281 & 1.57 & 0.116 & Younger \\
\hline $\begin{array}{l}\text { Engaged in serious violence that } \\
\text { you witnessed }\end{array}$ & 34.3 & 434 & 32.1 & 1193 & 36.2 & 1222 & 0.85 & 0.397 & 2.11 & 0.035 & 0.69 & 0.492 & - \\
\hline $\begin{array}{l}\text { At least one of the } 13 \mathrm{AHTO} \\
\text { experienced in past } 12 \text { months }\end{array}$ & 90.2 & 439 & 92.7 & 1211 & 95.7 & 1232 & 1.68 & 0.093 & 3.14 & 0.002 & 4.25 & $<0.001$ & Older \\
\hline
\end{tabular}

$N=$ sample size for each item

a Respondents were asked: "In the past 12 months, has someone who has been drinking ..."

b Listed age group reported a significantly $(p<0.05)$ higher proportion of experience

c Abbreviation of the phrase used in the survey: "Turned their back on you, rolled their eyes at you, gave dirty looks, ignoring you [sic] or did something else to you that was socially aggressive and designed to hurt you."

Note: Not all participants responded to all items. 
Table 4. Harms experienced due to others' drinking in the past 12 months, by perpetrator of harm

\begin{tabular}{|c|c|c|c|c|c|c|c|}
\hline \multirow[b]{3}{*}{ Harms experienced ${ }^{a}$} & \multicolumn{3}{|c|}{ Perpetrator of harm } & \multirow[b]{2}{*}{$\begin{array}{c}\text { Total } \\
\text { (all who } \\
\text { experienced } \\
\text { the harm) }\end{array}$} & \multirow{2}{*}{\multicolumn{3}{|c|}{$\begin{array}{l}\text { Two proportion Z-test for } \\
\text { known only vs stranger only }\end{array}$}} \\
\hline & $\begin{array}{l}\text { Known } \\
\text { only }\end{array}$ & $\begin{array}{l}\text { Stranger } \\
\text { only }\end{array}$ & $\begin{array}{l}\text { Both } \\
\text { known } \\
\text { and } \\
\text { stranger }\end{array}$ & & & & \\
\hline & $\%$ & $\%$ & $\%$ & $n$ & Z & $p$ & $\begin{array}{l}\text { More } \\
\text { likely }\end{array}$ \\
\hline Ruined a party or social gathering & 65.4 & 23.5 & 11.1 & 1870 & 16.22 & $<0.01$ & Known \\
\hline Ruined clothes or other belongings & 68.2 & 24.1 & 7.7 & 1355 & 17.05 & $<0.01$ & Known \\
\hline Given you unwanted sexual attention & 40.1 & 38.6 & 21.3 & 1745 & 0.58 & $>0.05$ & - \\
\hline Done something socially aggressivec & 60.4 & 26.8 & 12.8 & 1451 & 13.00 & $<0.01$ & Known \\
\hline $\begin{array}{l}\text { Made you afraid when you encountered } \\
\text { them on the street }\end{array}$ & 10.5 & 84.1 & 5.4 & 1104 & 28.46 & $<0.01$ & Stranger \\
\hline $\begin{array}{l}\text { Harassed or bothered at a party or some } \\
\text { other private setting }\end{array}$ & 34.0 & 52.5 & 13.5 & 1085 & 7.18 & $<0.01$ & Stranger \\
\hline $\begin{array}{l}\text { Harassed or bothered on the street or in a } \\
\text { public place }\end{array}$ & 12.9 & 81.4 & 5.7 & 1137 & 26.47 & $<0.01$ & Stranger \\
\hline Left you alone in an unsafe situation & 90.4 & 6.3 & 3.2 & 709 & 32.52 & $<0.01$ & Known \\
\hline $\begin{array}{l}\text { Yelled at, criticised or verbally } \\
\text { abused you }\end{array}$ & 55.3 & 34.2 & 10.5 & 1006 & 8.16 & $<0.01$ & Known \\
\hline Pushed or shoved you & 48.8 & 41.6 & 9.7 & 974 & 2.78 & $<0.01$ & Known \\
\hline Physically hurt you & 57.1 & 34.6 & 8.3 & 399 & 8.73 & $<0.01$ & Known \\
\hline Put you in fear & 34.6 & 54.4 & 11.0 & 794 & 7.66 & $<0.01$ & Stranger \\
\hline $\begin{array}{l}\text { Engaged in serious violence that } \\
\text { you witnessed }\end{array}$ & 30.1 & 54.9 & 15.0 & 974 & 9.63 & $<0.01$ & Stranger \\
\hline
\end{tabular}

a Respondents were asked: "In the past 12 months, has someone who has been drinking ..."

b Listed group were reported to have a significantly $(p<0.05)$ higher proportion of perpetration

Abbreviation of the phrase used in the survey: "Turned their back on you, rolled their eyes at you, gave dirty looks, ignoring you [sic] or did something else to you that was socially aggressive and designed to hurt you."

\section{Discussion}

This study provided insight into young risky drinkers, who are most vulnerable to AHTO but who are underrepresented in national surveys. We confirmed they were experiencing a high prevalence of a range of harms, most of which are not assessed in other datasets.

Risky-drinking adolescents reported experiencing AHTO at a rate two to three times higher than adolescents of the same age in the general population. ${ }^{5}$ More than one-third (36\%) of our sample reported being yelled at, criticised or verbally abused by a drinker, compared with $14 \%$ of adolescents in the general population who reported a drinker had verbally abused them. While 5\% of adolescents in the general population reported that a drinker physically abused them, $15 \%$ of participants in this study reported that a drinker had physically hurt them. One in eight (12\%) of adolescents in the general population experienced fear as a result of someone else's drinking, compared with more than one in four (28\%) adolescents in this study. Although this study's item phrasing is more inclusive, and it is unweighted to age distribution, these higher reports of AHTO indicate a genuine difference between adolescents with risky drinking patterns compared with other adolescents. Further comparisons between our results and earlier datasets ${ }^{2,24}$ for young people in the general population were more difficult to conduct because of differences in item wording and the significant trend toward adolescents abstaining from alcohol within the past 10 years. ${ }^{5}$

Consistent with the adult gender violence literature ${ }^{5}$, young women in our sample reported a greater range of AHTO, especially those harms characterised by fear and harassment. Females were more likely than males to experience unwanted sexual attention (females $71 \%$ vs males $47 \%$ ), be put in fear, and be harassed in public and private spaces. Males were more likely than females to report experiencing aggressive harms such as verbal or physical abuse (males $42 \%$ vs females $28 \%$ ). 
Previous studies suggest perpetrators of harms to others are more likely to be male. ${ }^{11}$ These gendered findings on AHTO may have policy implications as experiences of fear, but not necessarily verbal and physical abuse, have been shown to be associated with increases in support for alcohol regulation policies. ${ }^{25}$ That is, the experience of fear may be a driver of support for alcohol regulation, and this may in part explain why support for regulation is particularly apparent among women.

Broadly speaking, 18-19-year-olds were more likely to experience AHTO than younger teens. This is possibly due to the older age groups' increased consumption of alcohol in public spaces, and also perhaps due to their increased exposure to situations associated with harm through risky drinking per se. However, it is important to note that the harms were still high even among the younger groups who were predominantly drinking outside of the licensed venue context, and thus a different set of responses is required for younger teens.

Consistent with the literature ${ }^{2}$, fear-based AHTO were more commonly attributed to strangers than perpetrators who were known to the victim, and the more tangible harms such as verbal or physical abuse were more commonly inflicted by perpetrators who were known to victims. Harms included having clothes/other belongings ruined (68\% known vs $24 \%$ unknown), being yelled at (55\% known vs 34\% unknown) or being physically hurt (57\% known vs 35\% unknown). This study did not assess how the respondents specifically knew the perpetrators. However, unpublished work conducted by this team with over 600 risky-drinking 14-19-year-olds from Western Australia (WA) in 2016 using similar methods provides some insight (data available on request). In the WA study, $41 \%$ of respondents reported someone under the influence of alcohol yelling at, criticising or verbally abusing them in the past 12 months. The perpetrator(s) were friends (reported by 53\%), current/ ex-partners (16\%), parents (16\%), other relatives $(3 \%)$, other known persons (17\%) and others unknown to them (34\%). Previous studies have asked parents whether their children have been affected by others' drinking ${ }^{26}$; however, asking parents whether their own or others' drinking is affecting their child can be fraught with social desirability bias. In contrast, this study provides unique insight into whether young people have been harmed by their parents' and others' drinking from the young person's perspective.

\section{Strengths and limitations}

The strengths of this study are that it is one of the few studies about younger people not restricted to college students. Furthermore, we assessed 13 AHTO, as opposed to the three that are routinely assessed in the general population survey ${ }^{5}$, and also explored whether the perpetrators were known to the respondent.
This study's limitations include reliance on participants' perception/interpretation and self-report of another's intoxication. Our AHTO items were phrased so they would be comparable with a general population survey. ${ }^{5}$ However, the phrase "has someone who has been drinking ..." does not indicate specific attribution, that is, whether the victim thought the incident related to the drinking, or if the alcohol use was simply incidental. Although there was no external verification of incidents, certain harms can only be assessed by self-report - for example, internal states such as fear, and less severe harms such as having a party ruined, which would not be officially recorded elsewhere.

As the target population represented approximately $1 \%$ of Australian residents ${ }^{5,27}$, random sampling techniques were not feasible and participants were recruited using a purposive technique. Lastly, while the sample was at higher risk for victimisation and perpetration than the general population due to their age and drinking patterns, they did not otherwise show the hallmarks of marginalisation commonly identified in snowball samples recruited for other studies of drug use. ${ }^{28}$

\section{Conclusion}

In recent years it has become common for policy discussions around alcohol to consider the safety of the broader community, as well as that of the individual drinker. This has been evidenced by AHTO being included in the first priority area in the draft Australian national alcohol strategy 2018-202629 and also identified in the WHO Global strategy to reduce the harmful use of alcohol. ${ }^{30}$

This study found a high prevalence of a range of harms not assessed elsewhere. Many of these harms were not only an inconvenience, but have the potential to affect how young people live their lives. Young risky drinkers' problems are compounded by their own drinking, others' drinking and their relative inexperience in both these arenas. In addition, intoxication may compromise their capacity to deal with threats.

There are longer-term benefits to addressing these early social experiences of alcohol-related harms. The perception among young people that it is normal to experience AHTO can set up future expectations for their own and others' behaviours in a range of contexts, as well as tolerance of others' behaviours. ${ }^{31}$

From the perspective of young people themselves, they may believe that if they drink too much and hurt themselves it is their own choice, or that they can handle the consequences for themselves. However, evidence that lives other than theirs are affected may give them pause for thought. This may also be relevant for policy makers and the wider community. 


\section{Acknowledgements}

The research on which this report is based was funded by the Australian Government through the Department of Health (project D16-451850) and a Western Australian Health Promotion Foundation (Healthway) Research Fellowship (24106). The National Drug Research Institute (Curtin University), the National Drug and Alcohol Research Centre (UNSW) and the National Centre for Education and Training on Addiction (Flinders University) are supported by funding from the Australian Government under the Drug and Alcohol Program.

A-ML received funding from NHMRC (1090910) and ARC (DE 190100329). DL has received research grants from NHMRC, ARC and Beyond Blue and has received speaking honorariums from Astra Zeneca, Janssen, Lunbeck, Shire and Servier. His institution (Turning Point) has received consultancy fees from Indivior and Lundbeck. SL receives fees from Simon Lenton Consulting clinical psychology practice and has received travel expenses from MundiPharma Australia to attend an expert reference group meeting. SA has received grants from NHMRC, Healthway and WA Government, payment for lectures from UWA, travel expenses from the Australian Government Department of health and consultancy fees from the South Australian Government and Siggins Miller consultants.

\section{Peer review and provenance}

Externally peer reviewed, not commissioned.

\section{Competing interests}

None declared.

\section{Author contributions}

$T L$ and $A M L$ were responsible for drafting the manuscript, and overseeing the editing by RO, JF, DL, TC, RMidford and $S A$. TL, AML and $W L$ were responsible for the analysis and interpretation of the data. TL, SA, RO, DL, WL, TC, WG, SL, JF, LB, AA, RMa, and RMi contributed to the study design, collecting and interpreting the data, and reviewing the manuscript.

\section{References}

1. Australian Bureau of Statistics. Crime Victimisation, Australia, 2015-16. Canberra: ABS; 2017 [cited 2017 Sep 31]. Available from: www.abs.gov.au/AUSSTATS/ abs@.nsf/Lookup/4530.0Main+Features1201516?OpenDocument
2. Laslett A-M, Catalano P, Chikritzhs T, Dale C, Doran C, Ferris J, et al. The range and magnitude of alcohol's harm to others. Melbourne: AER Centre for Alcohol Policy Research, Turning Point Alcohol and Drug Centre, Eastern Health; 2010 [cited 2017 Oct 31]. Available from: fare.org.au/wp-content/uploads/The-Range-andMagnitude-of-Alcohols-Harm-to-Others.pdf

3. Collins DJ, Lapsley HM. The costs of tobacco, alcohol and illicit drug abuse to Australian society in 2004/05. Canberra: Commonwealth of Australia; 2008 [cited 2019 Oct 15]. Available from: nadk.flinders.edu.au/ files/3013/8551/1279/Collins__Lapsley_Report.pdf

4. Fillmore KM. The social victims of drinking. Br J Addict. 1985;80(3):307-14.

5. Australian Institute of Health and Welfare. National drug strategy household survey 2016: detailed findings. Canberra: AlHW; 2017 [cited 2019 Oct 15]. Available from: www.aihw.gov.au/getmedia/15db8c15-7062-4cdebfa4-3c2079f30af3/21028a.pdf.aspx?inline=true

6. Laslett A-M, Room R, Waleewong O, Stanesby O, Callinan S. Harm to others from drinking: patterns in nine societies. Geneva: World Health Organization; 2019 [cited 2019 Oct 23]. Available from: apps.who.int/iris/ bitstream/handle/10665/329393/9789241515368-eng. pdf?sequence $=1 \&$ isAllowed=y

7. Cabalatungan S, McCarthy B. Second-hand effects of college drinking and educational experiences: findings from an analysis of pooled cross-sections. Drugs: Education, Prevention and Policy. 2015;22(6):463-9.

8. Hallett J, Howat PM, Maycock BR, McManus A, Kypri K, Dhaliwal SS. Undergraduate student drinking and related harms at an Australian university: web-based survey of a large random sample. BMC Public Health. 2012;12(1):37.

9. Laslett A-M, Room R, Ferris J, Wilkinson C, Livingston M, Mugavin J. Surveying the range and magnitude of alcohol's harm to others in Australia. Addiction. 2011;106(9):1603-11.

10. Greenfield TK, Karriker-Jaffe KJ, Kerr WC, Ye Y, Kaplan LM. Those harmed by others' drinking in the US population are more depressed and distressed. Drug Alcohol Rev. 2016;35(1):22-9.

11. Davis MacNevin $P$, Thompson K, Teehan M, Stuart $H$, Stewart S. Is personality associated with secondhand harm from drinking? Alcohol Clin Exp Res. 2017;41(9):1612-21.

12. Thompson K, Davis-MacNevin P, Teehan M, Stewart $S$, Team TCCR. The association between secondhand harms from alcohol and mental health outcomes among postsecondary students. J Stud Alcohol Drugs. 2017;78(1):70-8.

13. Aiken A, Lam T, Gilmore W, Burns L, Chikritzhs T, Lenton S, et al. Youth perceptions of alcohol advertising in Australia: are current advertising regulations working? Aust N Z J Public Health. 2018;42(3):234-9. 
14. Wilson J, Ogeil RP, Lam T, Lenton S, Lloyd B, Burns L, et al. Re-thinking pre-drinking: implications from a sample of teenagers who drink in private settings. Int J Drug Policy. 2018;52:20-4.

15. Ogeil RP, Lloyd B, Lam T, Lenton S, Burns L, Aiken A, et al. Pre-drinking behavior of young heavy drinkers. Subst Use Misuse. 2016;51(10):1297-306.

16. Lam T, Lenton S, Ogeil R, Burns L, Aiken A, Chikritzhs T, et al. Most recent risky drinking session with Australian teenagers. Aust N Z J Public Health. 2017;41(1):105-10.

17. Lam T, Lenton S, Burns L, Aiken A, Ogeil R, Gilmore W, et al. Alcohol policy impact on young risky drinkers and their support for proposed measures. Aust N Z J Public Health. 2015;39(2):129-34

18. Australian Institute of Health and Welfare. National drug strategy household survey detailed report: 2013. Canberra: AlHW; 2014 [cited 2019 Oct 15]. Available from: www. aihw.gov.au/getmedia/c2e94ca2-7ce8-496f-a76594c55c774d2b/16835_1.pdf.aspx?inline=true

19. Victorian Drug and Alcohol Prevention Council. 2009 Victorian youth alcohol and drug survey. Melbourne: Victorian Drug and Alcohol Prevention Council; 2010 [cited 2019 Oct 15]. Available from:

s3.amazonaws.com/zanran_storage/www.health.vic.gov.au/ ContentPages/111167689.pdf

20. White V, Williams T. Australian secondary school students' use of tobacco, alcohol, and over-the-counter and illicit substances in 2014. Melbourne: Victorian Department of Health, Cancer Council Victoria; 2016 [cited 2019 Oct 15]. Available from: darta.net.au/wordpress-content/ uploads/2017/01/ASSAD-2014.pdf

21. Lam T, Lenton S, Chikritzhs T, Gilmore W, Liang W, Pandzic I, et al. Young Australians' Alcohol Reporting System (YAARS): national report 2016/17. Perth, WA: National Drug Research Institute, Curtin University; 2017 [cited 2019 Oct 15]. Available from: ndri.curtin.edu.au/NDRI/media/documents/yaars/yaars2016-17-final-report.pdf

22. Callinan S, Laslett A-M, Rekve D, Room R, Waleewong O, Benegal V, et al. Alcohol's harm to others: An international collaborative project. Int J Alcohol Drug Res. 2016;5(2):25-32.
23. ThaiHealth. The harm to others from drinking: a WHO/ ThaiHealth international collaborative research project. Melbourne: Centre for Alcohol Policy Research, LaTrobe University; 2012 [cited 2019 Oct 15]. Available from: www. capr.edu.au/wp-content/uploads/2012/08/H2O-WHO-THProtocol_for_web.pdf

24. Callinan S, Room R. Harm, tangible or feared: Young Victorians' adverse experiences from others' drinking or drug use. Int J Drug Policy. 2014;25(3):401-6.

25. Stanesby O, Rankin G, Callinan S. Experience of harm from others' drinking and support for stricter alcohol policies: Analysis of the Australian National Drug Strategy Household Survey. Int J Drug Policy. 2017;45:25-32.

26 Laslett A-M, Ferris J, Dietze P, Room R. Social demography of alcohol-related harm to children in Australia. Addiction. 2012;107(6):1082-9.

27. Australian Bureau of Statistics. Australian Demographic Statistics. Canberra: ABS; 2016 [cited 2017 Oct 31]. Available from: www.abs.gov.au/AUSSTATS/abs@.nsf/ Lookup/3101.0Explanatory\%20Notes1Sep\%202016

28 Peacock A, Uporova J, Karlsson A, Gibbs D, Swanton R, Kelly $G$, et al. Australian drug trends 2019: key findings from the National Illicit Drug Reporting System (IDRS) interviews. Sydney: National Drug and Alcohol Research Centre, UNSW; 2019 [cited 2019, Oct 23]. Available from: ndarc. med.unsw.edu.au/resource/key-findings-2019-nationalillicit-drug-reporting-system-idrs-interviews

29. Commonwealth of Australia as represented by the Department of Health. Consultation draft national alcohol strategy 2018-2026. Canberra: Commonwealth of Australia; 2018 [cited 2019, Oct 15]. Available from: www.health.gov.au/sites/default/files/draft-national-alcoholstrategy-2018-2026.pdf

30. World Health Organization. Global strategy to reduce the harmful use of alcohol. Geneva: WHO; 2010 [cited 2019 Oct 15]. Available from: www.who.int/substance_abuse/publications/global_ strategy_reduce_harmful_use_alcohol/en/

31. Lilleston PS, Goldmann L, Verma RK, McCleary-Sills J. Understanding social norms and violence in childhood: theoretical underpinnings and strategies for intervention. Psychol Health Med. 2017;22(sup1):122-34.

\section{Copyright: (C) (1) (2)}

(c) 2019 Lam et al. This article is licensed under the Creative Commons Attribution-NonCommercial-ShareAlike 4.0 International Licence, which allows others to redistribute, adapt and share this work non-commercially provided they attribute the work and any adapted version of it is distributed under the same Creative Commons licence terms. See: www.creativecommons.org/licenses/by-nc-sa/4.0/ 